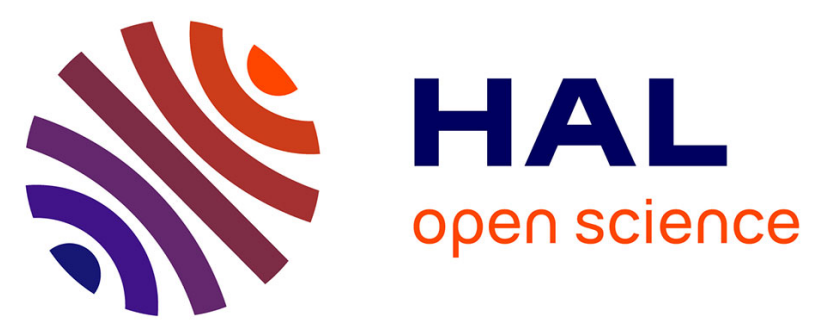

\title{
Recovery of ultramafic soil functions and plant communities along an age-gradient of the actinorhizal tree Ceuthostoma terminale (Casuarinaceae) in Sabah (Malaysia)
}

Celestino Quintela-Sabaris, Etienne Auber, Sukaibin Sumail, Jean-Francois Masfaraud, Michel-Pierre Faucon, Françoise Watteau, Ramez Saad, Antony van Der Ent, Rimi Repin, John Sugau, et al.

\section{- To cite this version:}

Celestino Quintela-Sabaris, Etienne Auber, Sukaibin Sumail, Jean-Francois Masfaraud, Michel-Pierre Faucon, et al.. Recovery of ultramafic soil functions and plant communities along an age-gradient of the actinorhizal tree Ceuthostoma terminale (Casuarinaceae) in Sabah (Malaysia). Plant and Soil, 2019, 440 (1-2), pp.201-218. 10.1007/s11104-019-04085-y · hal-02376402

\author{
HAL Id: hal-02376402 \\ https://hal.science/hal-02376402
}

Submitted on 22 Nov 2019

HAL is a multi-disciplinary open access archive for the deposit and dissemination of scientific research documents, whether they are published or not. The documents may come from teaching and research institutions in France or abroad, or from public or private research centers.
L'archive ouverte pluridisciplinaire HAL, est destinée au dépôt et à la diffusion de documents scientifiques de niveau recherche, publiés ou non, émanant des établissements d'enseignement et de recherche français ou étrangers, des laboratoires publics ou privés. 
1 Recovery of Ultramafic Soil Functions and Plant Communities along an Age-gradient of the Actinorhizal Tree Ceuthostoma terminale (Casuarinaceae) in Sabah (Malaysia)

5 Celestino Quintela-Sabarís ${ }^{1 *}$, Etienne Auber ${ }^{1}$, Sukaibin Sumail ${ }^{2}$, Jean-François Masfaraud ${ }^{3}$, 6 Michel-Pierre Faucon ${ }^{4}$, Françoise Watteau ${ }^{1}$, Ramez F. Saad ${ }^{1}$, Antony Van der Ent ${ }^{1,5}$, Rimi 7 Repin $^{2}$, John Sugau ${ }^{6}$, Reuben Nilus ${ }^{6}$, Guillaume Echevarria ${ }^{1}$, Sophie Leguedois ${ }^{1}$

$9 \quad{ }^{1}$ Laboratoire Sols et Environnement (UMR 1120 INRA- Université de Lorraine), Vandoeuvre les

10 Nancy, France

11 22Sabah Parks, Kota Kinabalu, Sabah, Malaysia

12 33Université de Lorraine, CNRS, LIEC, F-57000 Metz, France

$13{ }^{4}$ AGHYLE, Agroécologie, Hydrogéochimie, Milieux et Ressources (UP.2018.C101, SFR Condorcet

14 FR CNRS 3417), Institut Polytechnique UniLaSalle, Beauvais, France

15 5entre for Mined Land Rehabilitation, Sustainable Minerals Institute, The University of

16 Queensland, Queensland, Australia

$17{ }^{6}$ Forest Research Centre, Sabah Forestry Department, Sandakan, Sabah, Malaysia

18

$19 *$ Correspondence:

20 Dr. Celestino Quintela-Sabarís

21 tino.quintela.sabaris@gmail.com

23 Keywords: Nitrogen, Pioneer plants, Plant-soil interaction, Soil enzymes, Soil recovery, Tropical 24 areas 


\section{Abstract}

Background and aims Pioneer plants may improve the ecological restoration of degraded ultramafic areas by plant-soil interaction processes. In this study, we assess the effect of the pioneer actinorhizal tree C. terminale (Casuarinaceae) on the recovery of plant communities and soil functions on degraded tropical ultramafic sites.

Methods Soil and plant samples were collected along a tree-age gradient in two degraded ultramafic sites in Sabah (Northern Borneo, Malaysia): a Technosol and a Leptosol. Chemical composition of plants and soils, and biological activity of soils were assessed at both sites. Plant colonisation was assessed by plot vegetation surveys.

Results An improvement in soil fertility parameters ( $\mathrm{pH}$ reduction from 8.5 to 6.8, an increase in the concentrations of several nutrients and enhanced soil enzyme activities) was observed along the $C$. terminale age gradient. However, plant cover and diversity was only improved around mature trees at the site that was not impacted by mining.

Conclusion C. terminale promotes the recovery of several soil functions, mainly related to the storage and recycling of N, P, K, S. Besides plant-soil feedback, other environmental factors (i.e. exposition to sunlight, drought) may play an important role on revegetation of ultramafic soils.

\section{Introduction}

Ultramafic rocks are fragments of oceanic lithosphere or derivation of upper mantle materials that are locally abundant along tectonic plate margins (Echevarria 2018). Ultramafic bedrock consisting of the magnesium-iron-silicate peridotite can be altered by low-temperature metamorphism of peridotite ('serpentinization') leading to the formation of serpentine-group minerals (i.e. antigorite, chrysotile, lizardite) (Alexander 2004; Van der Ent et al. 2018).

Due to its chemical (richness in metals such as $\mathrm{Ni}, \mathrm{Cr}$ or $\mathrm{Co}$ ) and mineralogical properties (more than $90 \%$ of dark-colored mafic minerals such as olivine), ultramafic rocks have been mined for metal extraction or exploited for use as ornamental stones, road-base aggregate or railway track ballast (Guillot and Hattori 2013; Mudd and Jowitt 2014). Ultramafic rock-derived soils are also 
important areas for plant biodiversity, hosting a numerous endemic and threatened species (Van der

60 Ent et al. 2015a).

62 As a major component of terrestrial ecosystems, soils generate a range of important functions, such as biodiversity provisioning or storage, filtration, and transformation of substances (Adhikari and Hartemink 2016). Surface operations on ultramafic areas, such as mining or quarrying, degrade soil conditions by compaction and loss of topsoil, reducing the soil capacities to render these functions (Echevarria and Morel 2015). Moreover, non-stabilised ultramafic materials may constitute a source of air and water pollution, due to wind-borne dispersal of dust particles with asbestos and metals or leaching of pollutants to groundwater (O’Dell and Claassen 2009; Raous et al. 2010). Thus, revegetation of degraded ultramafic areas has several environmental benefits (Tordoff et al. 2000). However, restoration of ultramafic degraded sites is a complicated task that must address several typical characteristics of the material which severely limit the establishment of plants; i.e. low concentrations of essential nutrients, unbalanced calcium (Ca) and magnesium (Mg) concentrations, presence of potentially toxic concentrations of metals -mainly Ni and chromium (Cr)-, (Brady et al., 2005; Kazakou et al., 2008); as well as other properties related to soil fertility such as low cation exchange capacity (CEC) or low water holding capacity (WHC) (Bradshaw 1997; O’Dell and Claassen 2009). These harsh conditions may reach extreme values in serpentinite-derived soils in tropical areas: high total and exchangeable Mg, very high Mg:Ca molar quotients, low exchangeable $\mathrm{K}$ (down to $0.05 \mathrm{cmol}^{(+)} \mathrm{kg}^{-1}$ ), and circum-neutral $\mathrm{pH}$ at surface ( $\mathrm{pH} 7$ ), and highly alkaline at depth (up to pH 9.8) (Van der Ent et al. 2018).

In general, revegetation of human-degraded areas requires the recovery of a soil nutrient stock (nitrogen $(\mathrm{N})$, phosphorus $(\mathrm{P})$, potassium $(\mathrm{K})$ ) and organic matter sufficient to sustain ecosystem functions (Bradshaw 1997; Wong 2003). This nutrient stock can be built up by the application of stored topsoil or by the use of organic amendments (Tordoff et al. 2000; O’Dell and Claassen 2009). Pioneer species native to ultramafic substrates may be a feasible alternative for the revegetation of degraded areas, as they are already adapted to the particular conditions of local ultramafic soils (Whiting et al. 2004; Van der Ent et al. 2013).

90 Pioneer plants can ameliorate soil conditions as they are able to extract essential nutrients, such as $91 \mathrm{Ca}, \mathrm{P}, \mathrm{K}$, from soils, accumulate them in their biomass and then transfer them to the soil in litter organic matter (Bradshaw 1997, 2000). Nitrogen is stored in soils mainly in organic matter, although in some areas N-rich bedrock is an overlooked nitrogen source (Morford et al. 2011). 
94 Thus, in post-operation scenarios, where organic topsoil is usually lacking, fixation of atmospheric nitrogen $\left(\mathrm{N}_{2}\right)$ by legumes or actinorhizal plants is usually the only source of this essential nutrient in the ecosystems (Bradshaw 1997, 2000). Improvement of soil conditions by pioneer species has been proposed as one of the main theories explaining ecological succession (i.e. facilitation, Connell and Slatyer 1977). Thus, pioneer plants alleviate extreme soil conditions, making soil less suitable to themselves and more suitable to later successional species, which then colonise (Pulsford et al. 2016). Facilitation processes, which can be mediated by soil-plant interactions or other factors such as protection from excessive sunlight, have been important for ecological succession on extreme environments, such as mine tailings or ultramafic areas (McCoy et al. 1999; Yang et al. 2015).

103

South and Southeast Asia host the largest ultramafic areas in the world (Galey et al. 2017). Mining activities for Ni have a major impact on the biodiversity of ultramafic ecosystems in some countries of this region, such as Indonesia (Van der Ent et al. 2013). In Sabah (Malaysia, Northern Borneo), ultramafic soils occupy an area 3,500 $\mathrm{km}^{2}$, with the area around Mount Kinabalu hosting several substantial outcrops (Van der Ent et al. 2015b). Serpentinite-derived Hypermagnesic Leptosols around Mount Kinabalu typically have highly distinct plant communities, the so-called 'Pioneer Casuarina scrub' and 'Mature Mixed Casuarina forest' (Van der Ent et al. 2016).

Ceuthostoma terminale L.A.S. Johnson (Casuarinaceae), is a dioecious pioneer tree species distributed from Borneo to New Guinea, where it occupies ridges and slopes on ultramafic soils, where the rainforest canopy is interrupted (Johnson 1988) (Fig. 1A). C. terminale (and other Casuarinaceae, including Gymnostoma nobile and G. sumatranum) are the dominant species on serpentinite-soils in Sabah (Van der Ent et al. 2016). As other Casuarinaceae, C. terminale leaves are reduced to small scales, a plant strategy to deal with low soil fertility (Dörken and Parsons 2017). Thus, photosynthetic function is performed by the deciduous green branchlets (Fig. 1B). The Casuarinaceae exhibit actinorhizal plant species, which host nitrogen-fixing actinobacteria (e.g. Frankia) that facilitate N-assimilation by the plant (Benson and Dawson 2007). Root nodules have been found on C. terminale, although the specific Frankia-strain has not yet been identified (Fig. 122 1C).

Actinorhizal plants have shown an important role in primary succession (e.g. ecosystem development on moraines left by retreating glaciers, Bradshaw 2000), and are useful for the recovery of marginal soils and degraded mine areas (Valdés 2007; Sheoran et al. 2010). Most actinorhizal plants occur in boreal and temperate ecosystems in both hemispheres, and family 
species (mainly Casuarina equisetifolia) have been widely used for the revegetation of extremely degraded soils in tropical areas of America, Africa and Asia (Valdés 2007; Diagne et al. 2013). C. terminale has readily colonised ultramafic Technosols in an abandoned serpentinite quarry South of Kinabalu Park (Sabah, Malaysia) (C. Quintela-Sabarís, personal observation). At that site, C. terminale plants create litter layers that are colonised by different plant species. Thus, C. terminale may be an interesting species for the restoration of tropical degraded ultramafic areas.

We hypothesise that $C$. terminale locally alleviates harsh conditions on ultramafic soils by root and litter effects on soil properties, thereby facilitating the colonisation by other plant species. To test this hypothesis, we investigated two ultramafic sites where C. terminale is present: (i) a valley subjected to recurrent landslides, and; (ii) a quarry where the soils have been human-degraded. In order to assess possible plant-soil feedback effects by $C$. terminale, we studied the development of soil chemical and biological properties along an age-gradient of C. terminale plants and compared the herbaceous communities at each site.

\section{Material and Methods}

\section{Studied sites}

Two ultramafic areas from Sabah (Northern Borneo, Malaysia) were included in this study: (i) an old serpentine quarry near Bukit Kulung (hereafter "Kulung”), and; (ii) an ultramafic area in the valley of the Wuluh River (hereafter "Wuluh") (Fig. 2A). At both sites, C. terminale is a dominant species in the local landscape. Quarrying at the Kulung site was related to Mamut Copper Mine (MCM), which was abandoned about 20 years ago, when mining activities ceased (van der Ent and Edraki 2018). Currently, this area is included in the Bukit Hampuan Forest Reserve. The total surface of the quarry is about 1.5 ha. The soil is a Spolic Technosol composed of a shallow layer of serpentinite tailings on top of serpentinite bedrock. Hundreds of C. terminale plants are growing in the quarry, and several mature trees (up to $15 \mathrm{~m}$ tall) were also found (Fig. 2B). Around of each $C$. terminale plant, litter (composed of deciduous photosynthetic branchlets) accumulates below plant canopies. This layer may reach $40 \mathrm{~cm}$ thickness under mature trees.

Wuluh area is one of the three major serpentinite occurrences in Kinabalu Park (Van der Ent et al. 2018). The sampled site consists of several serpentinite landslides of different ages, from recent landslides without vegetation (area around 0.5 ha) to old landslides covered by a C. terminale dominated forest (Fig. 2C). The soils in recent landslides are Hypereutric (Hypermagnesic) Leptosols composed mainly of fine degraded serpentinite debris. In the old landslides, the soil is 
covered by a continuous thick layer of $C$. terminale branchlets (O Horizon), with a well-developed A-horizon (Van der Ent et al. 2018).

\section{Collection of samples}

At each site, a stratified sampling, following an age gradient of C. terminale plants, was undertaken. Nine (at Wuluh site) or ten (at Kulung site) non-vegetated (NV) soil samples were collected from sampling points separated at least $2 \mathrm{~m}$ from any vascular plant. Then, five plants from each of the following three age-classes (we used plant height as a proxy for age) were selected: saplings (S, height $<1 \mathrm{~m}$ ), young trees (YT, $1 \mathrm{~m}<$ height $<5 \mathrm{~m}$ ) and mature trees (MT, height $>10 \mathrm{~m}$, but in most cases around $15 \mathrm{~m}$ height), totaling 24-25 soils and 15 plants sampled per site. Soil samples were collected beneath the canopies of the selected plants. All soil samples were collected from the A-layer at 0-20 cm depth in both sites.; due to soil structure we were unable to sample deeper soil at Kulung (it was actually the serpentinite bedrock) and soils at Wuluh were sampled at the same depth to better compare soil evolution between sites. Litter samples (each composed by a $10 \times 15$ cm ziplock plastic bag full of litter) were collected if present. A sample of green branchlets was taken from the canopy of each selected plant. In order to investigate variation in soil structure near C. terminale plants, blocks of undisturbed soil were also collected from the superficial soil layer (excluding litter) using Kubiena boxes $(9 \times 6 \times 5 \mathrm{~cm})$ in three points (non-vegetated soil, soil close to a young tree and soil close to a mature tree). Kubiena boxes (Jongerius and Heintzberger 1963) with two open faces were slowly inserted into a ledge excavated in the soil. This was only possible in Wuluh, because the rocky nature of Technosol at Kulung prevented the insertion of the boxes. After extraction of the soil with a knife, the boxes were wrapped, secured against any disturbance in a container and transported to the laboratory.

Finally, in order to assess the effect of $C$. terminale litter layer on plant colonisation, several botanical surveys were setup at each site. The surface of the surveys varied to adapt to local conditions (e.g. tree density). In Kulung, eight mature trees (MT) were selected and 16 plots of $4 \times$ 4 m were delimited: eight on the area covered by litter layer around each tree and eight on NV soil next to each MT plot. In Wuluh, 15 sampling plots were delimited around each of the sampled trees. The surface of the plots was $1 \times 1 \mathrm{~m}$ for $\mathrm{S}$ and YT categories, and $2 \times 2$ for MT. Plant species (including ferns, grasses, forbs and woody seedlings) growing in each square were identified and the cover of each species in each plot was registered using Braun-Blanquet cover classes (BraunBlanquet 1964).

\section{Analysis of soil and plant samples}


197 Fresh soil samples were passed by a 5-mm sieve upon sampling, kept in plastic ziploc bags and stored for 6 to 8 weeks at $4^{\circ} \mathrm{C}$ until analyses. The activity of soil enzymes alkaline phosphatase, arylsulfatase, $\beta$-glucosidase and urease, and the degradation of Fluorescein Diacetate (FDA) were determined in soil fresh subsamples.

Urease activity was determined using the colorimetric method described by (Kandeler and Gerber 1988). Alkaline phosphatase, ß-glucosidase and arylsulfatase activities were determined using $p$ nitrophenol $(p N P)$ linked substrates, according to the modified method of Dick et al. (2013). Finally, fluorescein diacetate (FDA) hydrolytic activity of the soil was measured colorimetrically following the method of (Adam and Duncan 2001).

Soil subsamples were air-dried and passed through a 2-mm sieve. Soil $\mathrm{pH}$ was measured in $\mathrm{H}_{2} \mathrm{O}$, after 60 min shaking, using a 1:5 (v/v) ratio. Cation Exchange Capacity (CEC) was determined colorimetrically after treatment of the soil with a solution of cobalt hexamine trichloride $0.05 \mathrm{~N}$, following the standard method AFNOR NF-X 31-130. Exchangeable concentrations of $\mathrm{Ca}^{+2}, \mathrm{Mg}^{+2}$ and $\mathrm{K}^{+}$in the soil were determined on the filtered soil-cobalt hexamine extracts by ICP-AES

212 (Liberty II, Varian). Total soil C and N was estimated by combustion in a CHNS analyser (Vario 213 Micro Cube, Elementar, Germany). Soil available phosphorus (Olsen-P) was extracted with a solution of $\mathrm{NaHCO}_{3}$ and quantified by reaction with ascorbic acid, following the standard method AFNOR NF ISO 11263. Soil nickel availability was evaluated after extraction with DTPA-TEA (0.005 M DTPA with $0.01 \mathrm{M} \mathrm{CaCl}_{2}$ and $0.1 \mathrm{M}$ triethanolamine (TEA) at $\mathrm{pH} 7.3,1: 2 \mathrm{w} / \mathrm{v}, 2 \mathrm{~h}$ shaking) (Lindsay and Norvell 1978). Soil subsamples were ground in a ceramic mortar and $0.5 \mathrm{~g}$ of dry ground soil were digested in $2 \mathrm{~mL}$ of concentrated $\mathrm{HNO}_{3}$ and $6 \mathrm{~mL}$ of concentrated $\mathrm{HCl}$ on a hot plate at $105^{\circ} \mathrm{C}$. The final solutions were filtered $(0.45 \mu \mathrm{m}$ DigiFILTER, SCP science, Canada) and brought to volume (50 mL) with deionised water. Pseudo-total soil concentrations of Ca, Co, $\mathrm{Cr}, \mathrm{Fe}, \mathrm{K}, \mathrm{Mg}, \mathrm{Mn}, \mathrm{Ni}, \mathrm{P}$ and $\mathrm{S}$ were determined by analysis of the digests with ICP-AES (Liberty II, Varian).

The development of soil structure was observed in soil thin sections. These sections $(9 \times 6 \mathrm{~cm}, 20$ $\mu \mathrm{m}$-thick) were prepared according to the method described by Jongerius and Heintzberger (1975). In brief, the soil samples were carefully extracted from Kubiena boxes and dried by replacing water by acetone. Then, the samples were impregnated under vacuum with polyester resin (EPON 812, Shell). The consolidated bloc was cut in two equivalent parts. One part was fixed on a thin glass with the same size $(9 \times 6 \mathrm{~cm})$ and sliced until having a soil section of $20 \mu \mathrm{m}$. The thin sections were scanned using a flatbed scanner (EPSON V750 Perfection Pro) at 1200 dpi. Magnified images were obtained with a Leica stereomicroscope MZ FLIII microscope. 
232 Green branchlets were cleaned with tap water and rinsed with deionised water. Litter samples and 233 cleaned branchlets were dried $\left(60^{\circ} \mathrm{C}\right)$ until constant weight. Dry material was finely ground using a 234 ball mill. Subsamples $(0.5 \mathrm{~g})$ of dry and ground tissues were digested at $95^{\circ} \mathrm{C}$ in $2.5 \mathrm{~mL}$ of 235 concentrated $\mathrm{HNO}_{3}$ and $5 \mathrm{~mL}$ of $\mathrm{H}_{2} \mathrm{O}_{2}$ (30\%). The final solutions were filtered $(0.45 \mu \mathrm{m}$ 236 DigiFILTER) and completed up to $25 \mathrm{~mL}$ with deionised water. $\mathrm{Ca}, \mathrm{Co}, \mathrm{Cr}, \mathrm{K}, \mathrm{Mg}$, $\mathrm{Ni}$ and $\mathrm{P}$ 237 concentrations were measured by ICP-AES (Liberty II, Varian). C and N were quantified in dry 238 ground samples using a CHNS analyzer (Vario Micro Cube, Elementar, Germany).

240 Data analysis

241 The variation in soil properties along C. terminale age-gradient was assessed for each site (Wuluh 242 and Kulung) using a Principal Component Analysis (PCA). Differences in soil variables (pH, 243 concentrations of C, N, P, K and Ni-DTPA, CEC and FDA degradation) were further explored by 244 two-way ANOVAs, with the factors site (Wuluh vs. Kulung) and age-class (non-vegetated, saplings, 245 young trees and mature trees). The data were log-transformed to fit ANOVA assumptions.

246 Variation in concentrations of N, P, K and Ca in branchlets was assessed by blocked two-way 247 ANOVA (factors site and age-class). The differences within each site for these variables were 248 analyzed by separated one-way ANOVAs (factor age-class) followed by Tukey post-hoc analyses. 249 Information on development of soil structure provided by soil-thin sections was used to 250 complement soil chemical and biological data.

251 Differences in plant species composition between litter cover classes were assessed with 2D Non252 Metric Multidimensional Scaling (NMDS). NMDS were computed separately for each site (Wuluh 253 or Kulung). Moreover, plant species diversity in vegetation surveys was calculated using Shannon's 254 diversity index (H'). This index was computed with the following formula: $\mathrm{H}^{\prime}=-\Sigma p_{i} \ln \left(p_{i}\right)$, where $i$ 255 corresponds to each species in the survey and $p_{i}$ is the proportional abundance of species $i$. Species' 256 cover (assessed as Braun-Blanquet cover classes) was used as a proxy for the abundance of each 257 species. $H^{\prime}$ was computed with function diversity, and NMDS was computed using function 258 metaMDS, both of them from package vegan for $\mathrm{R}$ (Oksanen et al. 2017). Differences in species 259 diversity were assessed separately for each site using one-way ANOVAs. PCAs and ANOVAs were 260 performed in SPSS (v. 15, SPSS Inc., Chicago, IL, USA).

\section{Results}

263 Variation in soil properties

264 The non-vegetated (NV) soils from Kulung and Wuluh had extreme chemical properties 265 characteristic of ultramafic soils (table 1): high $\mathrm{pH}$, extremely low concentration of essential 266 nutrients N, P and K, extremely high concentrations of Mg, low CEC (with dominance of $\mathrm{Mg}^{2+}$ in 
the exchange complex) and low biological activity. The conditions in the NV soils from Wuluh were harsher than at Kulung as shown by pseudo-total $\mathrm{Ca}, \mathrm{K}$ and $\mathrm{P}$ and exchangeable $\mathrm{Ca}$ concentrations, which were lower than instrumental detection limit.

Principal components analyses (PCA) were performed using all soil samples from each site. The PCA performed on samples from Kulung (Technosol) identified six principal components (PC) that explained $87 \%$ of total variance. $\mathrm{pH}$ was negatively correlated to PC1 (28\% of variance), whereas CEC, variables related to organic matter $(\mathrm{C}, \mathrm{N})$ and biological activity (Alkaline-phosphatase, $\beta$ glucosidase) had positive contributions on PC1. The pseudo-total concentrations of K, P and S had positive loadings on PC2 (16\% variance), whereas arylsulfatase activity and FDA hydrolysis were positively correlated to both PCs. The projection of soil samples on the space determined by PCs showed a gradient from NV to mature tree (MT) soil samples along PC1 (Fig 3A). This indicated an improvement of parameters of soil chemical and biological fertility along C. terminale age classes (i.e. $\mathrm{pH}$ reduction, increase in CEC and exchangeable $\mathrm{K}$ and $\mathrm{Mg}$, increase in $\mathrm{C}$ and $\mathrm{N}$, increase in several microbial activities in the soil), but also an increase in available $\mathrm{Ni}$. It is interesting to note that during soil sampling at Kulung we found cluster roots in a C. terminale sapling. Cluster roots are bottle brush-like structures in roots with dense packing of root hairs. In samples from Wuluh site (Leptosol) four PCs, explaining $92 \%$ of variance, were determined. The first PC (54\% of variance) had negative contributions by $\mathrm{pH}$, as occurred in Kulung, and by pseudo-total $\mathrm{Mg}, \mathrm{Ni}$ and $\mathrm{Cr}$; whereas $\mathrm{CEC}$, pseudo-total concentrations of $\mathrm{C}, \mathrm{N}, \mathrm{P}, \mathrm{K}, \mathrm{S}$, exchangeable K, P-Olsen and all microbial enzyme activities were positively correlated to that PC. Pseudo-total concentrations of metals $\mathrm{Co}, \mathrm{Fe}, \mathrm{Mn}, \mathrm{Cr}$ and Ni had positive contributions on PC2 (20\% of variance). As was observed for Kulung, the soil samples in Wuluh were also arranged along an increasing fertility gradient in PC1 from NV samples (in the most negative positions of PC1) to MT (Fig 3B). Soil samples from saplings (S) had also positive values on PC2, which indicated an increase in pseudo-total concentrations of $\mathrm{Mn}$, Co and $\mathrm{Cr}$ on those samples. ANOVAs performed on ten selected variables, related to soil chemical fertility on ultramafic soils (pH, CEC, concentrations of C, N, pseudo-total Ca and Mg, Olsen P, exchangeable K and DTPAextractable Ni, and FDA degradation activity) showed an improvement of soil conditions along agegradient (i.e. factor age-class had significant effects for the ten variables) (Table 2, Fig. 4). For example, $\mathrm{N}$ concentrations increased from 0.01 and $0.03 \%$ in NV soil in Wuluh and Kulung to 0.36 and $0.12 \%$ in soil around mature trees in those sites. In all variables (except C, Mg and FDA degradation) there were significant interactions between site and age-class (i.e. responses along agegradient were different in each site). However, in most cases these parameters showed the same trend of variation -decrease $(\mathrm{pH})$ or increase (CEC, $\mathrm{N}, \mathrm{K}$, etc.) along time- in the two sites, and the significant interaction was due to the extremely high values of MT samples from Wuluh. Those 
samples were collected from the A-horizon below a thick organic horizon (in some places more than $60 \mathrm{~cm}$ thick), and two samples were excluded from the ANOVAs due to extremely high C concentrations (above 30\%, thus representing an O-horizon).

Complementary to information provided by chemical analyses, microscopic observation of soil thin layers taken from the Wuluh site revealed a distinct gradient of increased soil structure and organic matter enrichment from NV to MT soils (Fig. 5 and supplementary material figures 1 to 3 ). The profile in NV soil was essentially mineral (Fig. 5 A,D), without any apparent aggregated structure. Macro porosity occurred around thicker elements and vertical pores were also present. Meso and micro porosity were not evident, and were created as a function of the arrangement of mineral elements. Colour changes in the sample from YT (Fig. 5 B,E) suggested an enrichment in organic matter, and structure was observed. Meso porosity was more important and the first roots were present. The MT soil, collected below litter layer (Fig. 5 C,F) had a beige color that suggested the abundance of fine organic matter associated with mineral elements in aggregates. Roots were abundant and the structure gave the soil a higher porosity than in previous samples. The frequent observation of roots and faecal pellets was suggestive of abundant biological activity.

\section{Variation in branchlets and litter composition}

Despite very low concentrations of essential nutrients in the soil, $C$. terminale was able to accumulate high concentrations of N, P, K, S and Ca (overall means of $1.1 \%$ and 283, 3819, 616 and $7645 \mathrm{mg} \mathrm{kg}^{-1}$, respectively) in the photosynthetic branchlets (table 2). Moreover, the average Ca:Mg molar ratio in branchlets was close to two, and the metal concentrations were quite low (e.g. Fe and $\mathrm{Ni}$ are $42 \mathrm{mg} \mathrm{kg}^{-1}$ and $14.7 \mathrm{mg} \mathrm{kg}^{-1}$, respectively). The analysis of fresh (i.e. not degraded) litter samples showed that for several nutrients $(\mathrm{P}, \mathrm{K}, \mathrm{Na})$ concentrations in litter have been drastically reduced to values around $10 \%$ of those in the branchlets. In contrast, other elements were slightly reduced (e.g. C, N, S) or even increased their concentration (e.g. Fe, Mn, Ni) in litter (table 3).

ANOVA analyses conducted to assess possible differences between sites and age-classes for concentrations of $\mathrm{N}, \mathrm{P}, \mathrm{K}$ and $\mathrm{Ca}$ in branchlets of $\mathrm{C}$. terminale showed that only $\mathrm{K}$ concentrations increased with age of the plants (Table 4, Fig. 6). This trend of variation was similar in both sites, and $\mathrm{K}$ concentration in plants from Wuluh was always higher than plants from Kulung. $\mathrm{N}$ and $\mathrm{P}$ concentrations did not varied significantly for any of the factors. The Ca concentrations in plants from Kulung were higher than plants from Wuluh, and these differences were more marked in $\mathrm{S}$ and YT than in MT (Fig. 6).

Effects of litter cover on plant communities 
NMDS analyses revealed differences in plant community composition related to C. terminale litter cover at both sites. In Wuluh site $(2 \mathrm{D}$ stress $=0.18)$ plant communities in sampling points were grouped according to tree age classes. Major differences were found among age-classes and only small overlaps occurred between plant communities around S and YT, whereas communities around mature trees were clearly separated (Fig. 7A). This is congruent with a higher cover of several shrub and tree species (e.g. Macaranga kinabaluensis -MAKI-, Euphorbiaceae; Rapanea sp. -RASP-, Myrsinaceae) as well as pitcher plants (Nepenthes sp. -NESP-, Nepenthaceae) that were absent around YT and S. The species diversity increased with $C$. terminale age $\left(F_{2,12}=9.871, p=0.003\right)$. Tukey post-hoc test showed that $\mathrm{S}\left(\mathrm{H}^{\prime}=0.70\right)$ had lower diversity than $\mathrm{YT}\left(\mathrm{H}^{\prime}=1.30, p=0.031\right)$ and MT $\left(\mathrm{H}^{\prime}=1.56, p=0.003\right)$, whereas no difference was found between YT and MT.

In the case of Kulung, the space occupied in NMDS plot by plant communities growing on litter layers around MT greatly overlapped the space occupied by communities from NV Technosol (i.e. low differences in species composition and cover) (Fig. 7B). The most important differences could be related to the increased cover of the sedge Fimbristylis sp. -FISP- (Cyperaceae, also present in all sampled plots in Wuluh river) on litter layers, as well as the presence of different shrubs and trees (genera Macaranga and Melastoma), absent on NV soil. Moreover, no differences in diversity occurred between plant communities growing on MT $\left(H^{\prime}=1.15\right)$ and NV plots $\left(H^{\prime}=1.00\right)\left(F_{1,14}=\right.$ $0.577, p=0.460)$.

\section{Discussion}

Landscape and soil degradation through mining and quarrying activities further exacerbates the extreme conditions of ultramafic soils (O’Dell and Claassen 2009). This study shows that nonvegetated Technosols derived from serpentinite bedrock in Sabah have extremely low concentrations of the essential nutrients $\mathrm{N}, \mathrm{P}, \mathrm{K}, \mathrm{S}$ as well as reduced soil biological activity. These conditions are similar to non-vegetated Leptosols where the topsoil, which contains almost all soil nutrients and biota, was lost due to naturally-occurring landslides.

C. terminale is successful in its ability to colonise such harsh environments and to develop until mature individuals more than $15 \mathrm{~m}$ height, in spite of extreme conditions in the serpentinite-derived soils. The concentrations of $\mathrm{N}(1.1 \%), \mathrm{P}(0.03 \%)$ and $\mathrm{K}(3.8 \%)$ in C. terminale branchlets are remarkably high considering the very low availability of these elements in soils. Two morphophysiological traits are responsible for these relatively high nutrient values: i) the symbiotic relationship with $\mathrm{N}$-fixing Frankia actinobacteria, and ii) the presence of cluster roots.

It is known that inoculation with Frankia improves the nutrient status of the actinorhizal plant and enhances its growth (Sayed 2011). However, the abundance of Frankia in soils and its nodulation 
capacities can be limited by several biotic and abiotic factors (including soil moisture, $\mathrm{pH}$, salinity or the presence of toxic metals) (Diagne et al., 2013; Valdés, 2007). Thus, extreme soil conditions in mine areas may limit the application of actinorhizal plants for soil restoration. The presence of nodules in C. terminale roots from our study sites suggests that this particular Frankia strain is highly tolerant to the prevailing ultramafic soil conditions, although isolation of the bacterium and experiments in culture media will be needed to confirm this. To our knowledge, no study on the identification of Frankia species or strains associated to C. terminale has been undertaken to date.

Cluster roots are considered an adaptation in nutrient-poor soils. These structures release carboxylates into the rhizosphere to solubilise immobile forms of $\mathrm{P}$ and $\mathrm{Fe}$, increasing the availability and uptake of these elements (Skene 1998; Shane and Lambers 2005). There are no previous references to the presence of cluster roots in the genus Ceuthostoma, although they have been observed in several species of Casuarina, Allocasuarina and Gymnostoma (Diem et al. 2000). It is known that carboxylate release is able to mobilise other micronutrients -such as Mn- (Lambers et al. 2015). We hypothesise that in the case of $C$. terminale carboxylates may contribute to $\mathrm{K}$ mobilisation in the soils, thus explaining the high concentrations of this element in branchlets.

C. terminale has a high P- and K- resorption efficiency. Around 90\% of these elements is resorbed from the branchlets before abscission. In contrast, $\mathrm{N}$ resorption is lower (around 38\%) and elements with low mobility (such as $\mathrm{Ca}$ ) have similar concentrations in litter and in branchlets. Compared to global analyses on nutrient resorption in plants (Vergutz et al. 2012), the values of P- and Kresorption are higher in $C$. terminale than the global average for nitrogen-fixing evergreen angiosperms ( $\mathrm{P}, 57.4 \%$; $\mathrm{K}, 41.0 \%$ ), whereas $\mathrm{N}$ resorption is quite similar to the global average for nitrogen-fixers (41.8\%) (Vergutz et al. 2012). These values are congruent with the different availability of each element. Nitrogen is not a limiting factor to a $\mathrm{N}$-fixer as $C$. terminale and thus its resorption is less critical for plant success, whereas a highly conservative $-\mathrm{P}$ and $-\mathrm{K}$ strategy is favoured in nutrient-poor serpentinite soils.

Individual trees have the ability to modify soil conditions via differential elemental uptake and release of organic matter via shoots (litterfall) or roots (root exudates or root turnover) (Binkley and

401 Giardina 1998). Regarding shoots, concentrations of nutrients in senesced leaves influence 402 ecosystem nutrient cycling by affecting litter quality and litter decomposition rates (Hayes et al. 403 2014). The high C:N and N:P ratios in C. terminale litter are limits for its degradability and explain 404 the presence of thick litter layers around mature trees. Recalcitrant (i.e. difficult to degrade) litter is 405 a common trait in slow growing species from nutrient poor habitats (De Deyn et al. 2008). 406 Moreover, it seems to be characteristic for the Casuarinaceae family, as attested by observations in 
Casuarina equisetifolia (Maharudrappa et al. 2000; Sayed 2011) and in Gymnostoma

408

409

deplancheanum (McCoy et al. 1999). Recalcitrant litter typically improves soil carbon inputs (a positive effect in ultramafic soils) but tends to immobilise nutrients, depending mainly on saprophytic fungi for degradation (De Deyn et al. 2008), and thus limiting the release of nutrients to the soil. Nevertheless, our results show a clear effect of $C$. terminale on soil properties, with minor differences between sites that can be related to differences in the starting soil conditions (e.g. extremely low extractable $\mathrm{Ca}$ and high extractable $\mathrm{Mg}$ at the Wuluh site). The most important changes were: (i) a marked $\mathrm{pH}$ reduction (that can be related to incorporation of organic matter to the soil, root exudates -especially carboxylates from cluster roots- and $\mathrm{N}_{2}$ biological fixation (Bolan et al. 1991)), and (ii) an increase in organic matter (indicated by higher $\mathrm{C}$ and $\mathrm{N}$ concentrations) with consequent increases in CEC, exchangeable $\mathrm{Ca}$ and $\mathrm{K}$ and specially in soil biological activity. The improvement of soil properties was graded along age-classes: on average, the older the plant, the higher the soil fertility. For instance, FDA degradation, which has potential to broadly represent soil enzyme activity and accumulated biological effects (Dick et al. 1996), showed a 10-fold increase from NV to MT soils in both sites. These results are in line with findings by Izquierdo et al. (2005), who observed that forestation trials with Casuarina equisetifolia on mined ultramafic soils from Cuba yielded the highest improvements in soil biological activity, and these improvements increased with the age of the plantation. Moreover, a meta-analysis on plant individual effects on soil properties also indicated that stronger modifications of soil properties by plants were observed in old tree plantations with light management (Waring et al. 2015).

The most positive fertility parameters were found beneath mature trees from Wuluh (i.e. the nonanthropised area). These trees (average height $20 \mathrm{~m}$ ) were presumably older than MT from Kulung (average height $13 \mathrm{~m}$ ). Thus, soils beneath MT from Wuluh have been subjected to $C$. terminale effects for longer time, which implied the formation of thicker litter layers and also a longer period for the degradation of the recalcitrant litter (see above) and its incorporation to soil.

The soils degraded by natural (e.g. landslides) or human (e.g. quarrying) impacts have reduced capacities to render several functions such as water filtration or nutrient storage (Echevarria and Morel 2015). Observed changes in soil properties along C. terminale age-gradient indicate the recovery of several important soil functions, such as the carbon pool, nutrient storage (increased $\mathrm{N}$, $\mathrm{P}, \mathrm{K}$, Ca concentrations), nutrient cycling (increased enzyme activities related to cycles of $\mathrm{C}, \mathrm{N}, \mathrm{P}$ and S), soil organic matter degradation (increased degradation of FDA) (Burges et al. 2016). Overall, these results provide insights into the positive role of the actinorhizal plant $C$. terminale to obtain functional ecosystems in degraded areas.

Plant facilitation plays an important role in the colonisation and succession and in the structuration of plant communities on ultramafic soils (McCoy et al. 1999; Oviedo et al. 2014). This facilitation 
442 may occur through the improvement of chemical properties of the soil (i.e. increased nutrient 443 supply), but also through the provision of shaded sites that reduce drought stress and excessive 444 insolation on seedlings during the first few years of growth (McCoy et al. 1999; Rigg et al. 2002). 445 Colonisation and development of $C$. terminale trees on ultramafic soils have improved soil fertility 446 at both studied sites. Despite the clear changes in soil conditions, changes in plant communities 447 growing around $C$. terminale plants were more subtle. Along the $C$. terminale age-gradient we 448 observed an increase in the cover of some shrub and tree species (Macaranga sp., Melastoma sp., 449 Breynia sp.) and the reduction of the cover of some herbaceous plants (Selaginella sp., Schizaea 450 spp.) and C. terminale (e.g. no C. terminale saplings were found below mature trees), although two 451 herbaceous species (the grass Mischantus floridulus and especially the sedge Fimbristylis sp.) had 452 an abundant cover in all the age classes, thus reducing the differences among plant communities. 453 Overall, a clear shift in composition of plant communities was only observed around mature trees of 454 Wuluh, whereas similar communities grow in plots on non-vegetated soil and around mature trees 455 from Kulung. Moreover, an increase in plant diversity was found only around young and matures 456 trees from Wuluh. Both results (shifts in composition or increase of biodiversity) suggest that the 457 facilitation effects on plant communities occurred only around mature trees at the Wuluh site. It was 458 hypothesised that one of the facilitation effects of Gymnostoma deplancheanum on ultramafic soils 459 from New Caledonia was related to shading (McCoy et al. 1999). Moreover, experiments on 460 controlled conditions showed that only plants with small seeds ( $2 \mathrm{~mm}$ ) were able to establish on 461 top of $G$. deplancheanum litter layers: small seeds were washed down the layer and stayed in humid 462 microsites whereas species with large seeds (>6 mm) dried out on litter surface and were unable to 463 establish (McCoy et al. 1996). Our observations indicate that other environmental factors besides 464 improvement of soil chemical parameters (i.e. exposition to sunlight and drought) may have an 465 important role on the recovery of plant communities on ultramafic soils. C. terminale plants at 466 Kulung were growing isolated and fully exposed to sunlight. In this situation, surface of litter layer 467 gets dry easily, creating hostile conditions for seed germination. At Wuluh, the plant density was 468 higher and, in the case of mature trees, they formed a dense forest with a continuous litter layer. 469 Thus, we hypothesise that the higher plant diversity around mature trees at Wuluh is the result of a 470 dense tree cover at this site and increased shading of the litter layer. As a consequence, litter is kept 471 humid for a longer time favoring the germination and establishment of more plant species. 472 However, the validity of this tentative explanation should be tested under controlled conditions.

474 In conclusion, the establishment and growth of $C$. terminale has improved soil chemical and 475 biological parameters and important soil functions, such as nutrient conservation and cycling. 476 Moreover, a change in community structure and an improvement in the diversity of plant 
communities was observed around mature trees growing on soil disturbed by landslides. Overall, C. terminale appears to be a promising species for the restoration of degraded serpentinite soils in SE Asia and Melanesia. However, the application of this species in ecological restoration programs need the development of more research in: (i) plant reproduction, including knowledge about seed viability and strategies for vegetative multiplication; (ii) agronomical practices, especially in relation to planting density and management of litter layers to favor establishment of new species, and, (iii) exploration of soil biota, with special emphasis on symbiotic arbuscular mycorrhiza fungi and also saprophytic fungi able to degrade $C$. terminale litter.

\section{Acknowledgements}

Sabah Biodiversity Centre provided C. Quintela-Sabarís with the Access and Export Licences to develop this research in Sabah (Malaysia). Local support provided by Mr. Geofarry Gunsalam and personnel in Monggis Substation (Kinabalu Park) is warmly acknowledged. C. Quintela-Sabarís Postdoctoral contract and this research have been funded by the French National Research Agency through the national program "Investissements d'avenir" with the reference ANR-10-LABX-21-01/ LABEX RESSOURCES21, and by Region Lorraine (France). A. van der Ent is the recipient of a Discovery Early Career Researcher Award (DE160100429) from the Australian Research Council.

\section{References}

Adam G, Duncan H (2001) Development of a sensitive and rapid method for the measurement of total microbial activity using fluorescein diacetate (FDA) in a range of soils. Soil Biol Biochem 33:943-951

Adhikari K, Hartemink AE (2016) Linking soils to ecosystem services-A global review. Geoderma 262:101-111

Alexander EB (2004) Serpentine soil redness, differences among peridotite and serpentinite materials, Klamath Mountains, California. Int Geol Rev 46:754-764

Benson DR, Dawson JO (2007) Recent advances in the biogeography and genecology of symbiotic Frankia and its host plants. Physiol Plant 130:318-330

Binkley DAN, Giardina C (1998) Why do tree species affect soils? The warp and woof of tree-soil interactions. In: Plant-induced soil changes: Processes and feedbacks. Springer, pp 89-106

Bolan NS, Hedley MJ, White RE (1991) Processes of soil acidification during nitrogen cycling with emphasis on legume based pastures. Plant Soil 134:53-63

Bradshaw A (1997) Restoration of mined lands—using natural processes. Ecol Eng 8:255-269

Bradshaw A (2000) The use of natural processes in reclamation - advantages and dificulties. Landsc Urban Plan 51:89-100

Brady KU, Kruckeberg AR, Bradshaw Jr HD (2005) Evolutionary ecology of plant adaptation to serpentine soils. Annu Rev Ecol Evol Syst 36:243-266

Braun-Blanquet J (1964) Pflanzensociologie: Grundzüge der Vegetationskunde, 3rd edn. SpringerVerlag, Vienna, Austria 
Burges A, Epelde L, Benito G, et al (2016) Enhancement of ecosystem services during endophyteassisted aided phytostabilization of metal contaminated mine soil. Sci Total Environ 562:480-492

Connell JH, Slatyer RO (1977) Mechanisms of succession in natural communities and their role in community stability and organization. Am Nat 111:1119-1144

Dawson JO (2007) Ecology of actinorhizal plants. In: Pawlowski K, Newton WE (eds) Nitrogenfixing actinorhizal symbioses. Springer, pp 199-234

De Deyn GB, Cornelissen JH, Bardgett RD (2008) Plant functional traits and soil carbon sequestration in contrasting biomes. Ecol Lett 11:516-531

Diagne N, Arumugam K, Ngom M, et al (2013) Use of Frankia and actinorhizal plants for degraded lands reclamation. BioMed Res Int 2013:

Dick LK, Jia G, Deng S, Dick RP (2013) Evaluation of microplate and bench-scale $\beta$-glucosidase assays for reproducibility, comparability, kinetics, and homogenization methods in two soils. Biol Fertil Soils 49:1227-1236

Dick RP, Breakwell DP, Turco RF (1996) Soil enzyme activities and biodiversity measurements as integrative microbiological indicators. In: Doran JW, Jones AJ (eds) Methods for assessing soil quality. SSSA, Madison, pp 247-271Diem HG, Duhoux E, Zaid H, Arahou M (2000) Cluster roots in Casuarinaceae: role and relationship to soil nutrient factors. Ann Bot 85:929-936

Dörken VM, Parsons RF (2017) Morpho-anatomical studies on the leaf reduction in Casuarina: the ecology of xeromorphy. Trees 1-13

Echevarria G (2018) Genesis and behaviour of ultramafic soils and consequences for nickel biogeochemistry. In: Baker AJM, Echevarria G, Morel J-L, Van der Ent A (eds) Agromining: Extracting Unconventional Resources From Plants. Springer Nature, Cham, Switzerland, pp 135-156

Echevarria G, Morel JL (2015) Technosols of mining areas. In: Araújo CW, de Souza VS, Galvão MB, Rodrigues E (eds) Tópicos em Ciência do Solo. Sociedade Brasileira de Ciência do Solo, Brasil, pp 92-111

Galey ML, Van der Ent A, Iqbal MCM, Rajakaruna N (2017) Ultramafic geoecology of South and Southeast Asia. Bot Stud 58:18

Guillot S, Hattori K (2013) Serpentinites: essential roles in geodynamics, arc volcanism, sustainable development, and the origin of life. Elements 9:95-98

Hayes P, Turner BL, Lambers H, Laliberté E (2014) Foliar nutrient concentrations and resorption efficiency in plants of contrasting nutrient-acquisition strategies along a 2 million year dune chronosequence. J Ecol 102:396-410

Izquierdo I, Caravaca F, Alguacil MM, et al (2005) Use of microbiological indicators for evaluating success in soil restoration after revegetation of a mining area under subtropical conditions. Appl Soil Ecol 30:3-10

Johnson LAS (1988) Notes on Casuarinaceae III: The new genus Ceuthostoma. Telopea 3:133-137 
Jongerius A, Heintzberger G (1975) Methods in soil micromorphology: a technique for the preparation of large thin sections. Stichting voor Bodemkartering Wageningen

Jongerius A, Heintzberger G (1963) The preparation of mammoth-sized thin sections. Netherlands Soil Survey Institute, Wageningen

Kandeler E, Gerber H (1988) Short-term assay of soil urease activity using colorimetric determination of ammonium. Biol Fertil Soils 6:68-72

Kazakou E, Dimitrakopoulos PG, Baker AJM, et al (2008) Hypotheses, mechanisms and trade offs of tolerance and adaptation to serpentine soils: from species to ecosystem level. Biol Rev 83:495-508

Kirkby E (2012) Introduction, definition and classification of nutrients. In: Marschner P (ed) Marschner’s Mineral Nutrition of Higher Plants (Third Edition). Elsevier, pp 3-5

Lambers H, Hayes PE, Laliberté E, et al (2015) Leaf manganese accumulation and phosphorusacquisition efficiency. Trends Plant Sci 20:83-90

Lindsay WL, Norvell WA (1978) Development of a DTPA soil test for zinc, iron, manganese, and copper. Soil Sci Soc Am J 42:421-428

Maharudrappa A, Srinivasamurthy CA, Nagaraja MS, et al (2000) Decomposition rates of litter and nutrient release pattern in a tropical soil. J Indian Soc Soil Sci 48:92-97

McCoy S, Jaffré T, Rigault F, Ash JE (1999) Fire and succession in the ultramafic maquis of New Caledonia. J Biogeogr 26:579-594

McCoy SG, Ash J, Jaffré T (1996) The effect of Gymnostoma deplancheanum (Casuarinaceae) litter on seedling establishment of new caledonian ultramafic maquis species. Australian Centre for Minesite Rehabilitation Research

Morford SL, Houlton BZ, Dahlgren RA (2011) Increased forest ecosystem carbon and nitrogen storage from nitrogen rich bedrock. Nature 477:78-81

Mudd GM, Jowitt SM (2014) A detailed assessment of global nickel resource trends and endowments. Econ Geol 109:1813-1841

O’Dell RE, Claassen VP (2009) Serpentine revegetation: a review. Northeast Nat 16:253-271

Oksanen J, Blanchet G, Friendly M, et al (2017) vegan: Community Ecology Package. R package version 2.4-4

Oviedo R, Faife-Cabrera M, Noa-Monzón A, et al (2014) Facilitation allows plant coexistence in Cuban serpentine soils. Plant Biol 16:711-716

Pulsford SA, Lindenmayer DB, Driscoll DA (2016) A succession of theories: purging redundancy from disturbance theory. Biol Rev 91:148-167 
Raous S, Becquer T, Garnier J, et al (2010) Mobility of metals in nickel mine spoil materials. Appl Geochem 25:1746-1755

Rigg LS, Enright NJ, Perry GLW, Miller BP (2002) The Role of Cloud Combing and Shading by Isolated Trees in the Succession from Maquis to Rain Forest in New Caledonia. Biotropica 34:199-210

Sayed WF (2011) Improving Casuarina growth and symbiosis with Frankia under different soil and environmental conditions. Folia Microbiol (Praha) 56:1-9

Shane MW, Lambers H (2005) Cluster roots: a curiosity in context. Plant Soil 274:101-125

Sheoran V, Sheoran AS, Poonia P (2010) Soil reclamation of abandoned mine land by revegetation: a review. Int J Soil Sediment Water 3:Article 13

Skene KR (1998) Cluster roots: some ecological considerations. J Ecol 86:1060-1064

Tordoff GM, Baker AJM, Willis AJ (2000) Current approaches to the revegetation and reclamation of metalliferous mine wastes. Chemosphere 41:219-228

Valdés M (2007) Frankia ecology. In: Pawlowski K, Newton WE (eds) Nitrogen-fixing Actinorhizal Symbioses. Springer, pp 49-71

Van der Ent A, Baker AJM, Van Balgooy MMJ, Tjoa A (2013) Ultramafic nickel laterites in Indonesia (Sulawesi, Halmahera): mining, nickel hyperaccumulators and opportunities for phytomining. J Geochem Explor 128:72-79

Van der Ent A, Cardace D, Tibbett M, Echevarria G (2018) Ecological implications of pedogenesis and geochemistry of ultramafic soils in Kinabalu Park (Malaysia). Catena 160:154-169

Van der Ent A, Edraki M (2018) Environmental geochemistry of the abandoned Mamut Copper Mine (Sabah) Malaysia. Environ Geochem Health 40:189-207

Van der Ent A, Erskine PD, Mulligan DR, et al (2016) Vegetation on ultramafic edaphic "islands" in Kinabalu Park (Sabah, Malaysia) in relation to soil chemistry and elevation. Plant Soil 403:77-101

Van der Ent A, Rajakaruna N, Boyd R, et al (2015a) Global research on ultramafic (serpentine) ecosystems (8th International Conference on Serpentine Ecology in Sabah, Malaysia): a summary and synthesis. Aust J Bot

Van der Ent A, Repin R, Sugau J, Wong KM (2015b) Plant diversity and ecology of ultramafic outcrops in Sabah (Malaysia). Aust J Bot 63:204-215

Vergutz L, Manzoni S, Porporato A, et al (2012) Global resorption efficiencies and concentrations of carbon and nutrients in leaves of terrestrial plants. Ecol Monogr 82:205-220

Waring BG, Álvarez-Cansino L, Barry KE, et al (2015) Pervasive and strong effects of plants on soil chemistry: a meta-analysis of individual plant 'Zinke'effects. Proc R Soc B Biol Sci 282:20151001 
Whiting SN, Reeves RD, Richards D, et al (2004) Research priorities for conservation of metallophyte biodiversity and their potential for restoration and site remediation. Restor Ecol 12:106-116

Wong MH (2003) Ecological restoration of mine degraded soils, with emphasis on metal contaminated soils. Chemosphere 50:775-780

Yang R, Guo F, Zan S, et al (2015) Copper tolerant Elsholtzia splendens facilitates Commelina communis on a copper mine spoil. Plant Soil 397:201-211 
Table 1 Description of non-vegetated soils from Bukit Kulung quarry (ultramafic Technosol) and 499 Wuluh River (ultramafic Leptosol). Mean values $(n=9-10)$ are presented, units are indicated for 500 each variable. $\mathrm{P}$ and $\mathrm{K}$ pseudo-total concentrations in Kulung, and S pseudo-total concentrations in 501 both sites are below limit of quantification (K, $\left.150 \mathrm{mg} \mathrm{kg}^{-1} ; \mathrm{P}, 52 \mathrm{mg} \mathrm{kg}^{-1} ; \mathrm{S}, 224 \mathrm{mg} \mathrm{kg}^{-1}\right)$, but are 502 presented for comparative purposes.

503

\begin{tabular}{ccc}
\hline Variable & \multicolumn{2}{c}{ Site } \\
\cline { 2 - 3 } & Kulung & Wuluh \\
\hline $\mathrm{pHH}_{2} \mathrm{O}$ & 7.98 & 9.09 \\
$\mathrm{C}$ and N (\%) & & \\
$\mathrm{C}$ & 0.53 & 0.39 \\
$\mathrm{~N}$ & 0.03 & 0.01 \\
$\mathrm{C}: \mathrm{N}$ ratio & 15.5 & 31.8
\end{tabular}

Pseudo-total concentrations of major and trace elements (mg kg-1)

\begin{tabular}{|c|c|c|}
\hline $\mathrm{Ca}$ & $2,580.7$ & $<$ d.l. \\
\hline $\mathrm{Fe}$ & $5710^{3}$ & $38.510^{3}$ \\
\hline $\mathrm{K}$ & 72.6 & $<$ d.l. \\
\hline $\mathrm{Mg}$ & $234.810^{3}$ & $255.310^{3}$ \\
\hline Mn & $1,297.5$ & 633.2 \\
\hline $\mathrm{P}$ & 11.66 & $<$ d.l. \\
\hline $\mathrm{S}$ & 133.58 & 67.43 \\
\hline Co & 115.36 & 70.6 \\
\hline $\mathrm{Cr}$ & $1,222.4$ & 948.3 \\
\hline $\mathrm{Ni}$ & $2,187.9$ & $1,647.4$ \\
\hline Olsen P (mg kg $\left.{ }^{-1}\right)$ & 1.4 & 1.33 \\
\hline DTPA-extractable Ni (mg kg-1) & 18.95 & 38.36 \\
\hline \multicolumn{3}{|c|}{ CEC and Exchangeable cations $\left(\mathrm{cmol}_{\mathrm{c}} \mathrm{kg}^{-1}\right)$} \\
\hline CEC & 7.98 & 1.69 \\
\hline $\mathrm{Ca}$ & 1.47 & 0 \\
\hline $\mathrm{Mg}$ & 5.82 & 4.31 \\
\hline $\mathrm{K}$ & 0.02 & 0.01 \\
\hline Ca:Mg molar quotient & 0.23 & 0 \\
\hline \multicolumn{3}{|c|}{ Soil microbial activities ( $\mu$ g product $\mathrm{g}^{-1} \mathrm{~h}^{-1}$ ) } \\
\hline Alkaline Phosphatase & 13.14 & 0.79 \\
\hline Arylsulfatase & 1.76 & 0.07 \\
\hline$\beta$-Glucosidase & 34.28 & 31.73 \\
\hline Urease & 2.03 & 0.55 \\
\hline FDA hydrolysis & 0.75 & 3.53 \\
\hline
\end{tabular}


Table 2 Two-way ANOVAs of ten variables related to soil chemical and biological fertility in two ultramafic sites (Kulung and Wuluh) and 4 age-classes (non-vegetated, sapling, young tree and mature tree) (for each site, $n=9-10$ in NV class and $n=5$ in S, YT and MT classes). Site and ageclass were fixed factors, all variables (except $\mathrm{pH}$ ) were log-transformed to meet ANOVA

510 assumptions. Each line corresponds to one ANOVA. P: ${ }^{* * *} \mathrm{p}<0.001,{ }^{* *} \mathrm{p}<0.01,{ }^{*} \mathrm{p}<0.05$, ns $=$ not significant.

\begin{tabular}{|c|c|c|c|c|c|c|c|c|c|c|}
\hline \multirow{2}{*}{ Variable } & \multicolumn{3}{|c|}{$\begin{array}{l}\text { Site } \\
(\mathrm{df}=1)\end{array}$} & \multicolumn{3}{|c|}{$\begin{array}{l}\text { Age-class } \\
(\mathrm{df}=3)\end{array}$} & \multicolumn{3}{|c|}{$\begin{array}{l}\text { Site*Age-class } \\
\quad(\mathrm{df}=3)\end{array}$} & \multirow{2}{*}{$\begin{array}{c}\begin{array}{c}\text { Error } \\
(\mathrm{df}=39)\end{array} \\
\mathrm{MS}\end{array}$} \\
\hline & MS & $\mathrm{F}$ & $\mathrm{p}$ & MS & $\mathrm{F}$ & $\mathrm{p}$ & MS & $\mathrm{F}$ & $\mathrm{p}$ & \\
\hline $\mathrm{pH}$ & 3.12 & 42.0 & $* * *$ & 7.2 & 97.0 & $* * *$ & 0.69 & 9.3 & $* * *$ & 0.07 \\
\hline $\mathrm{C}$ & 0.004 & 0.1 & ns & 2.2 & 45.9 & $* * *$ & 0.1 & 2.7 & ns & 0.05 \\
\hline $\mathrm{N}$ & 0.002 & 0.1 & ns & 2.0 & 55.5 & $* * *$ & 0.3 & 9.4 & $* * *$ & 0.04 \\
\hline P-Olsen & 1.38 & 27.6 & $* * *$ & 1.30 & 26.0 & $* * *$ & 1.04 & 20.7 & $* * *$ & 0.05 \\
\hline $\mathrm{K}_{\text {Exch }}$ & 0.003 & 0.1 & ns & 1.14 & 37.7 & $* * *$ & 0.20 & 6.7 & $* *$ & 0.03 \\
\hline CEC & 0.26 & 15.6 & $* * *$ & 1.14 & 69.4 & $* * *$ & 0.45 & 27.5 & $* * *$ & 0.02 \\
\hline Ca & 51.12 & 229.6 & $* * *$ & 3.39 & 15.2 & $* * *$ & 3.76 & 16.9 & $* * *$ & 0.22 \\
\hline $\mathrm{Mg}$ & 0.00 & 0.3 & ns & 0.01 & 3.1 & $*$ & 0.00 & 2.22 & ns & 0.00 \\
\hline FDA & 4.82 & 70.0 & $* * *$ & 2.50 & 36.3 & $* * *$ & 0.13 & 1.9 & ns & 0.07 \\
\hline $\mathrm{Ni}_{\text {DTPA }}$ & 0.002 & 0.0 & ns & 0.71 & 10.0 & $* * *$ & 0.52 & 7.4 & $* * *$ & 0.07 \\
\hline
\end{tabular}


Table 3 Chemical composition of $C$. terminale photosynthetic branchlets and litter. Mean values for branchlets $(n=15)$ and litter $(n=9-15)$ are presented for each site and averaged for all samples. Units are indicated for each variable. $\mathrm{P}$ and $\mathrm{S}$ concentrations in litter are below limit of quantification (P, $125 \mathrm{mg} \mathrm{kg}^{-1}$; S, $525 \mathrm{mg} \mathrm{kg}^{-1}$ ), but are presented for comparative purposes.

\begin{tabular}{|c|c|c|c|c|c|c|c|}
\hline \multirow{2}{*}{ Variable } & \multicolumn{3}{|c|}{ Branchlets } & \multicolumn{3}{|c|}{ Litter } & \multirow{2}{*}{$\begin{array}{c}\text { Average element } \\
\text { concentrations in plants } \\
\text { (Kirkby 2012) }\end{array}$} \\
\hline & Kulung & Wuluh & $\begin{array}{c}\text { Overall } \\
\text { mean }\end{array}$ & Kulung & Wuluh & $\begin{array}{c}\text { Overall } \\
\text { mean }\end{array}$ & \\
\hline \multicolumn{8}{|c|}{$\mathrm{C}$ and $\mathrm{N}(\%)$} \\
\hline $\mathrm{C}$ & 49.8 & 52.0 & 50.9 & 50.2 & 51.4 & 50.6 & - \\
\hline $\mathrm{N}$ & 1.1 & 1.0 & 1.1 & 0.8 & 0.7 & 0.8 & 1.5 \\
\hline $\mathrm{C}: \mathrm{N}$ ratio & 46.2 & 50.0 & 48.1 & 63.7 & 73.6 & 67.4 & - \\
\hline \multicolumn{8}{|c|}{ Pseudo-total concentrations of major and trace elements (mg kg-1) } \\
\hline $\mathrm{P}$ & 278.1 & 288.6 & 283.3 & 4.3 & 65.4 & 28.2 & 2,000 \\
\hline K & 2,600 & 5,037 & 3,819 & 255 & 316 & 279 & 10,000 \\
\hline $\mathrm{Ca}$ & 8,464 & 6,827 & 7,645 & 9,317 & 7,005 & 8,412 & 5,000 \\
\hline $\mathrm{Mg}$ & 2,214 & 4,073 & 3,144 & 1,581 & 4,847 & 2,859 & 2,000 \\
\hline $\begin{array}{c}\text { Ca:Mg } \\
\text { quotient }\end{array}$ & 2.75 & 1.17 & 1.96 & 4.18 & 1.3 & 3.05 & - \\
\hline $\mathrm{Fe}$ & 49 & 36 & 42 & 95 & 245 & 154 & 100 \\
\hline Mn & 98 & 75 & 86 & 119 & 88 & 107 & 50 \\
\hline $\mathrm{Na}$ & 912.5 & 722.6 & 817.6 & 65.9 & 77.0 & 70.2 & - \\
\hline S & 674.3 & 558.5 & 616.4 & 418.9 & 371.7 & 400.4 & 1,000 \\
\hline $\mathrm{Zn}$ & 10.0 & 9.9 & 10.0 & 12.3 & 9.1 & 11.0 & 20 \\
\hline $\mathrm{Ni}$ & 18.5 & 11.0 & 14.7 & 19.5 & 24.8 & 21.6 & 0.1 \\
\hline
\end{tabular}

Table 4 Two-way ANOVAs of N, P, K and Ca concentration in branchlets of C. terminale of two ultramafic sites (Kulung and Wuluh) and 3 age-classes (sapling, young tree and mature tree; for each site and age-class, $n=5$ ). Site and age-class were fixed factors. Each line corresponds to one ANOVA. P: $* * * \mathrm{p}<0.001, * * \mathrm{p}<0.01, * \mathrm{p}<0.05$, ns $=$ not significant.

\begin{tabular}{|c|c|c|c|c|c|c|c|c|c|c|}
\hline \multirow{2}{*}{ Variable } & \multicolumn{3}{|c|}{$\begin{array}{c}\text { Site } \\
(\mathrm{df}=1)\end{array}$} & \multicolumn{3}{|c|}{$\begin{array}{l}\text { Age-class } \\
(\mathrm{df}=2)\end{array}$} & \multicolumn{3}{|c|}{$\begin{array}{l}\text { Site*Age-class } \\
\quad(\mathrm{df}=2)\end{array}$} & \multirow{2}{*}{$\begin{array}{c}\begin{array}{c}\text { Error } \\
(\mathrm{df}=24)\end{array} \\
\mathrm{MS}\end{array}$} \\
\hline & MS & $\mathrm{F}$ & $\mathrm{p}$ & MS & $\mathrm{F}$ & $\mathrm{p}$ & MS & $\mathrm{F}$ & $\mathrm{p}$ & \\
\hline $\mathrm{N}$ & 0.02 & 0.6 & ns & 0.05 & 2.0 & ns & 0.04 & 1.7 & ns & 0.03 \\
\hline $\mathrm{P}$ & 828.5 & 0.12 & ns & $10,698.2$ & 1.5 & ns & $7,476.1$ & 1.0 & ns & 7,147.07 \\
\hline K & $44,545,341$ & 21.8 & $* * *$ & $14,491,438$ & 7.1 & $* *$ & 801,580 & 0.4 & ns & $2,047,074$ \\
\hline $\mathrm{Ca}$ & $20,109,475$ & 8.3 & $* *$ & $2,419,290$ & 1.0 & ns & $8,357,718$ & 3.5 & $*$ & $2,413,940$ \\
\hline
\end{tabular}




\section{FIGURE CAPTIONS}

Figure 1 A, mature C. terminale tree (height $\sim 15 \mathrm{~m}$ ) growing in an abandoned serpentine quarry. $\mathbf{B}$, detail of photosynthetic branchlets. The scale-like leaves are arranged in whorls (4 leaves per whorl). The yellow arrow marks one of the furrows where the stomata are hidden. $\mathbf{C}$, mass of Frankia nodules recovered from $C$. terminale roots. Note the grey mineral particles of ultramafic soil attached to the nodule surface. Photos A and C are from C. Quintela-Sabarís, photo B from F. Watteau.

Figure 2 Studied sites. A, regional map of SE Asia and local map ( $\mathrm{N}$ of Borneo) showing the sampled areas (red stars in local map). Dark grey polygons mark protected areas in Sabah. B, detail of the abandoned serpentinite quarry of Bukit Kulung. Two young C. terminale trees can be seen in the right foreground, and several mature trees are seen in the background. Note the reddish litter layer below their canopies. $\mathbf{C}$, detail of a small landslide in Wuluh river, with several young $C$. terminale trees growing in the open area. Photos from C. Quintela-Sabarís.

Figure 3 PCA analysis of soil samples from Kulung (A) and Wuluh (B). In each graph, soil samples are marked with different colors according to the age-class (NV, non-vegetated; S, sapling; YT, young tree; MT, mature tree). Empty dots mark the centroid for each group, with lines connecting to each of the samples (for each site, $n=9-10$ in NV class and $n=5$ in S, YT and MT classes). For each site, contributions of soil variables to each of the two first Principal Components (PC) are indicated in the insets. Pseudo-total concentrations of elements are indicated by their chemical symbol; $C N$, $\mathrm{C} / \mathrm{N}$ ratio; $\mathrm{CaMg}, \mathrm{Ca} / \mathrm{Mg}$ molar ratio; $\mathrm{CEC}$, cation exchange capacity; $\mathrm{Ca}^{2+}, \mathrm{K}^{+}, \mathrm{Mg}^{2+}$, exchangeable concentrations of $\mathrm{Ca}, \mathrm{K}$ and $\mathrm{Mg}$; $N i_{D T P A}$, DTPA-extractable Ni concentration; $A P$, alkalinephosphatase; $A R Y$, arylsulfatase; $B G, \beta$-glucosidase; FDA, FDA degradation; $U R$, urease.

Figure 4 Variation in selected soil properties along age-gradient of Ceuthostoma terminale. In each graph, average values ( \pm SD) in each site (blue color, Kulung; green color, Wuluh) for each ageclass (NV, non-vegetated; S, saplings; YT, young trees; MT, mature trees) are presented (for each site, $n=9-10$ in NV class and $n=5$ in S, YT and MT classes). Different capital and small-case letters indicate significant differences ( $p<0.05$, Tukey post-hoc test) among age-classes in Kulung and Wuluh sites, respectively.

Figure 5 Structure in soil samples from non vegetated (A, D), young tree (B, E) and mature tree (C, F) sampling points in at the Wuluh site. Images $\mathbf{D}$ to $\mathbf{F}$ are detailed views from the white marked areas in images $\mathbf{A}$ to $\mathbf{C}$. D, example of thick mineral element in the middle of a finer mineral matrix, pore with air bubbles (as artifacts) to the right. E, different root sections and yet unidentified root structures present in pores. F, longitudinal section of a root in the middle of organo-mineral matrix, thick mineral element to the right.

Figure 6 Variation in the concentrations of N, P, K and Ca in branchlets of $C$. terminale along an age-gradient. In each graph, average values ( \pm SD) in each site (blue, Kulung; green, Wuluh) for each age-class (S, saplings; YT, young trees; MT, mature trees) are presented ( $\mathrm{n}=5$ for each site and age-class). Different capital and small-case letters indicate significant differences $(\mathrm{p}<0.05$, Tukey post-hoc test) among age-classes in Kulung and Wuluh, respectively.

Figure 7 NMDS analyses of plant communities around C. terminale plants at Wuluh (A) and Kulung (B) sites. Colored polygons are convex hulls connecting plant communities on bare soil (gray), and around C. terminale saplings (blue), young trees (yellow) and mature trees (green) (for each class, $n=8$ at Kulung and $n=5$ at Wuluh). Red letter codes indicate plant species (see supplementary material Table S2). 
574 Fig. 1:
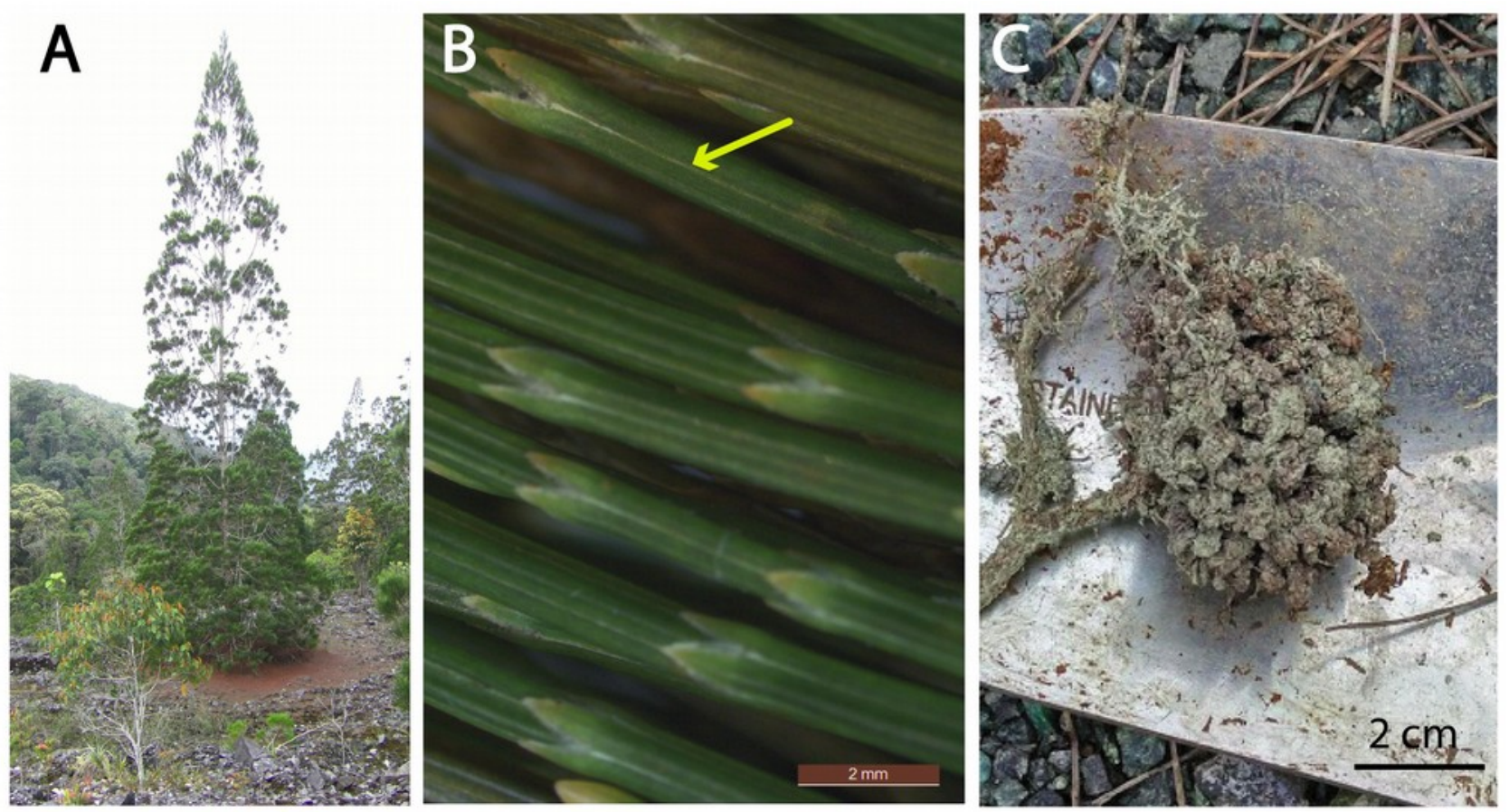
575 Fig. 2:

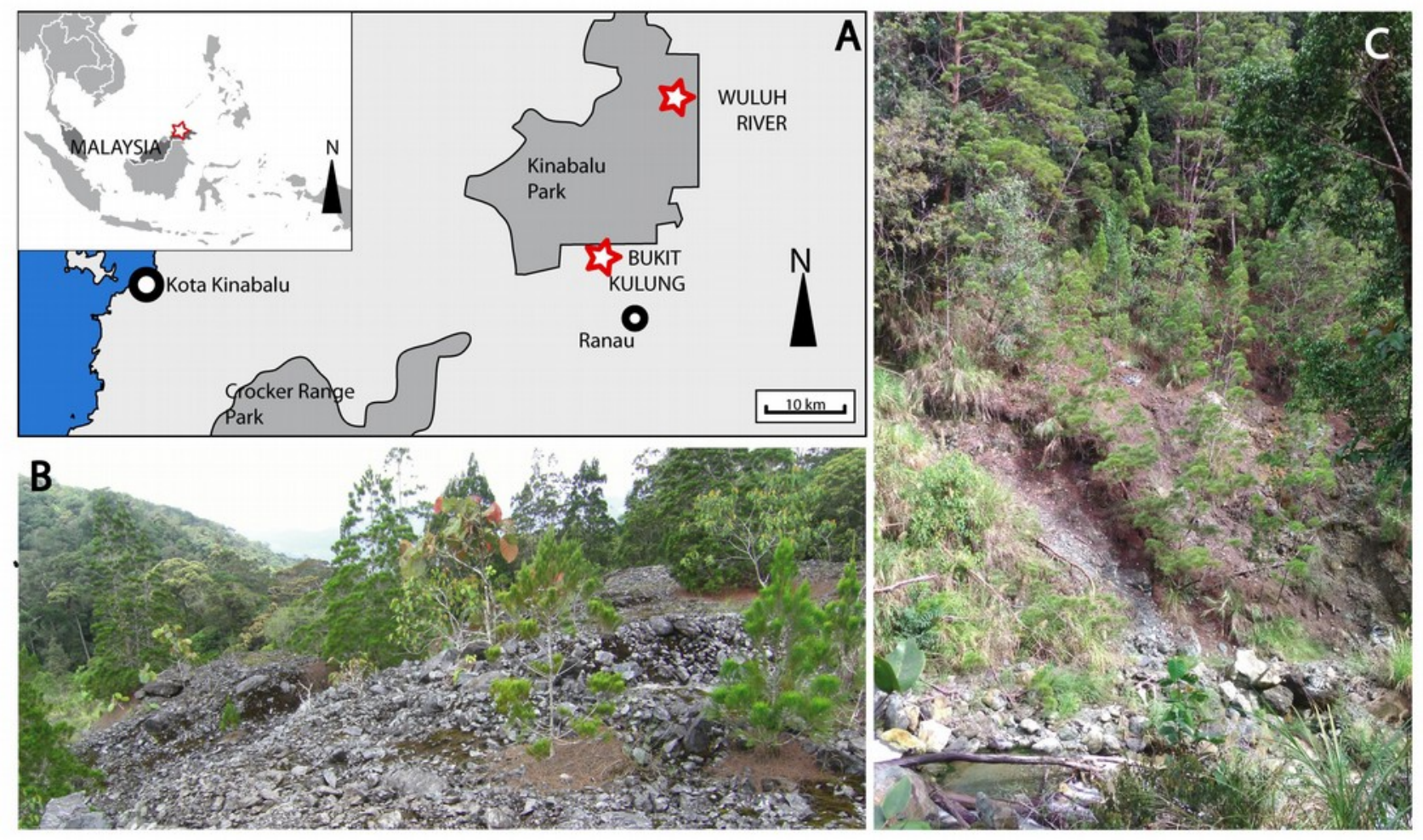

577 
578 Fig 3:

579

580
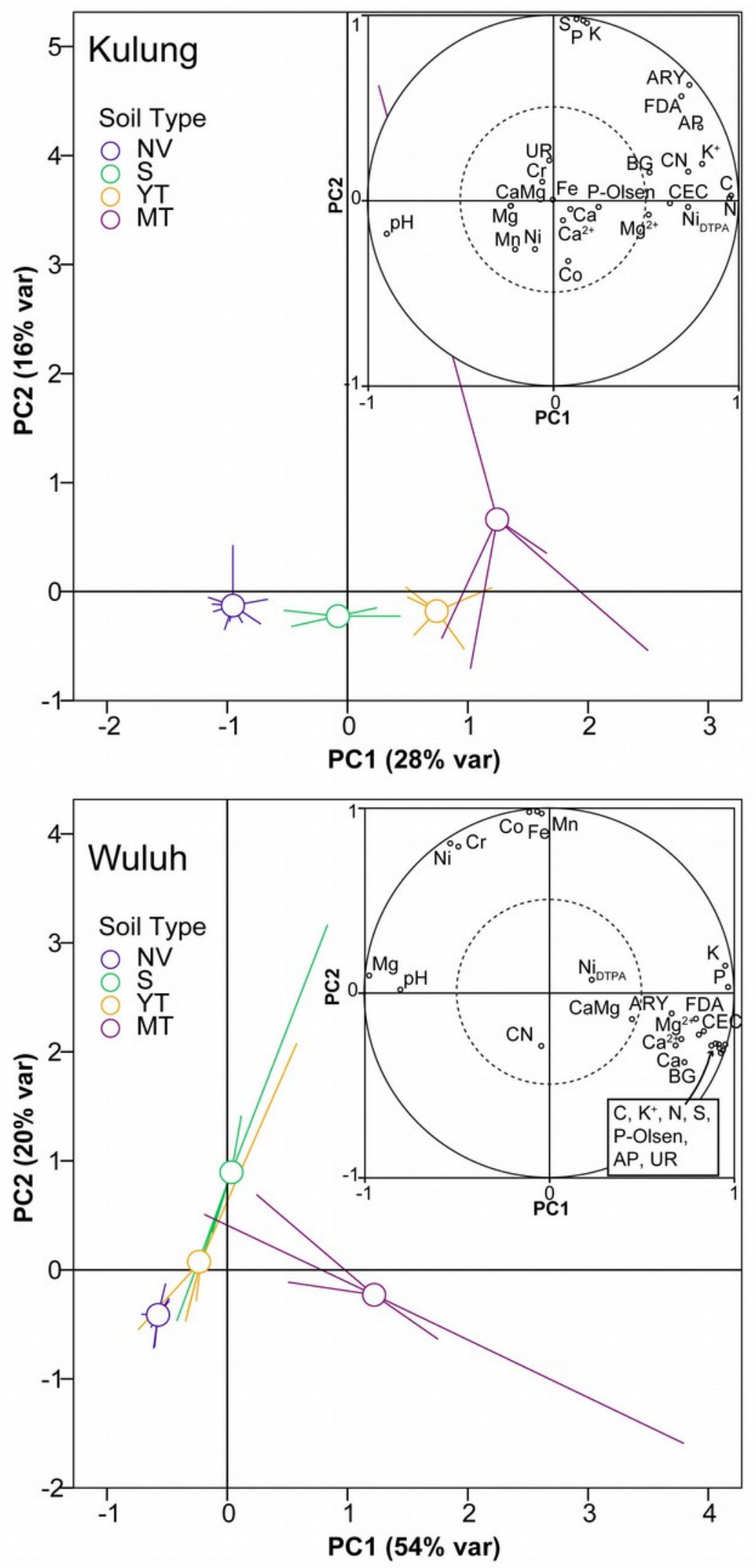
581

582

583
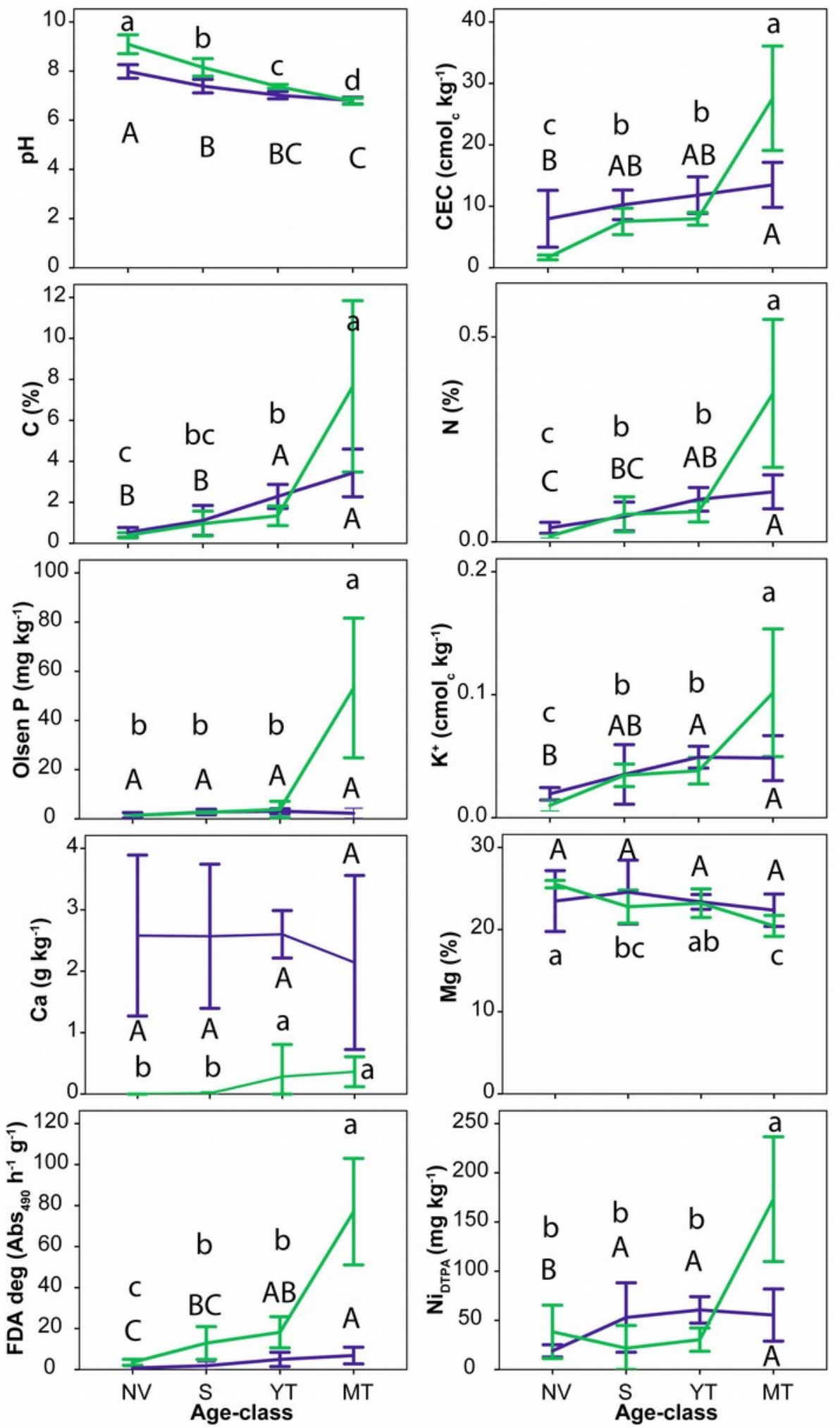
584 Fig. 5:

585

586
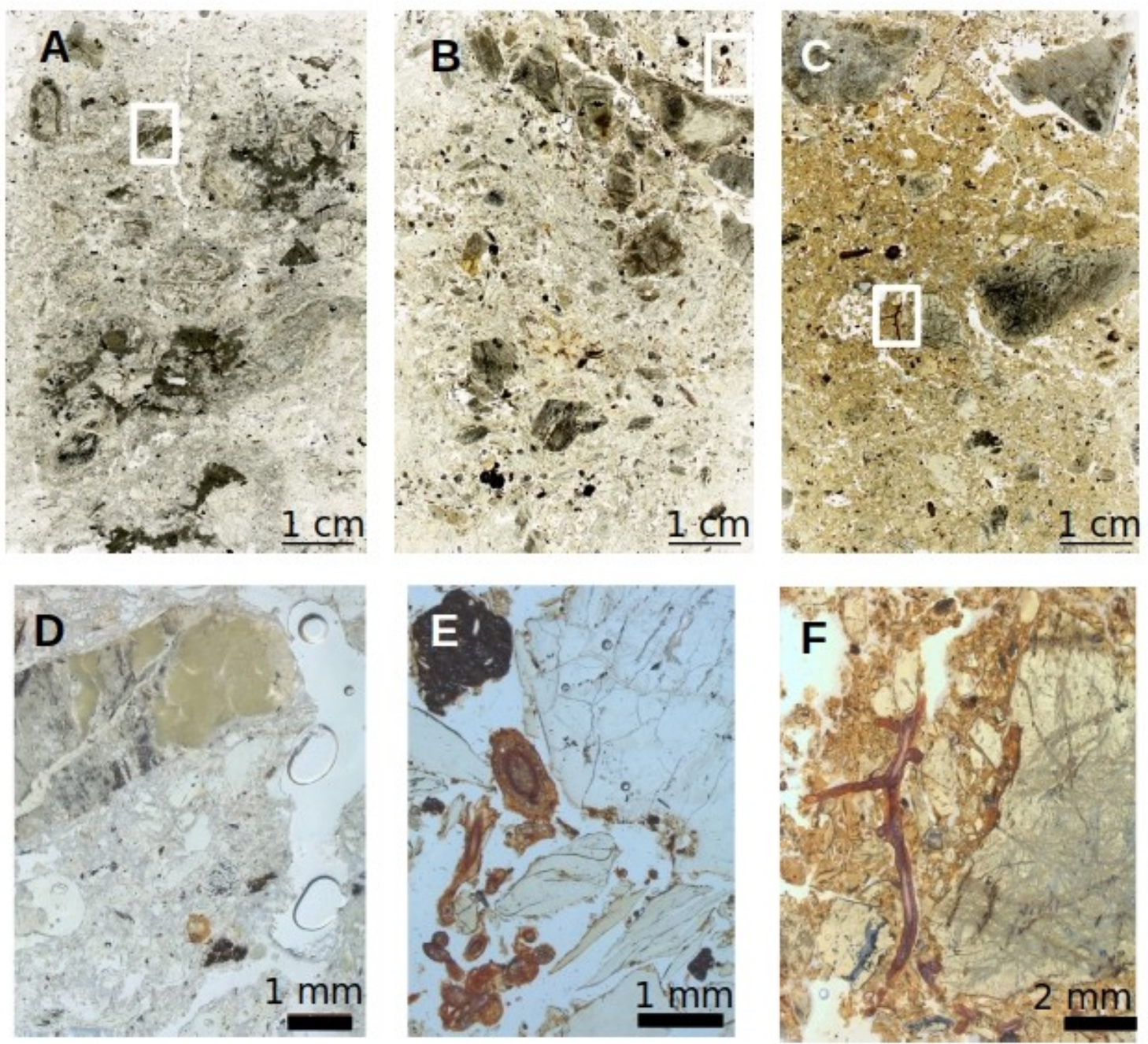
587 Fig. 6:

588
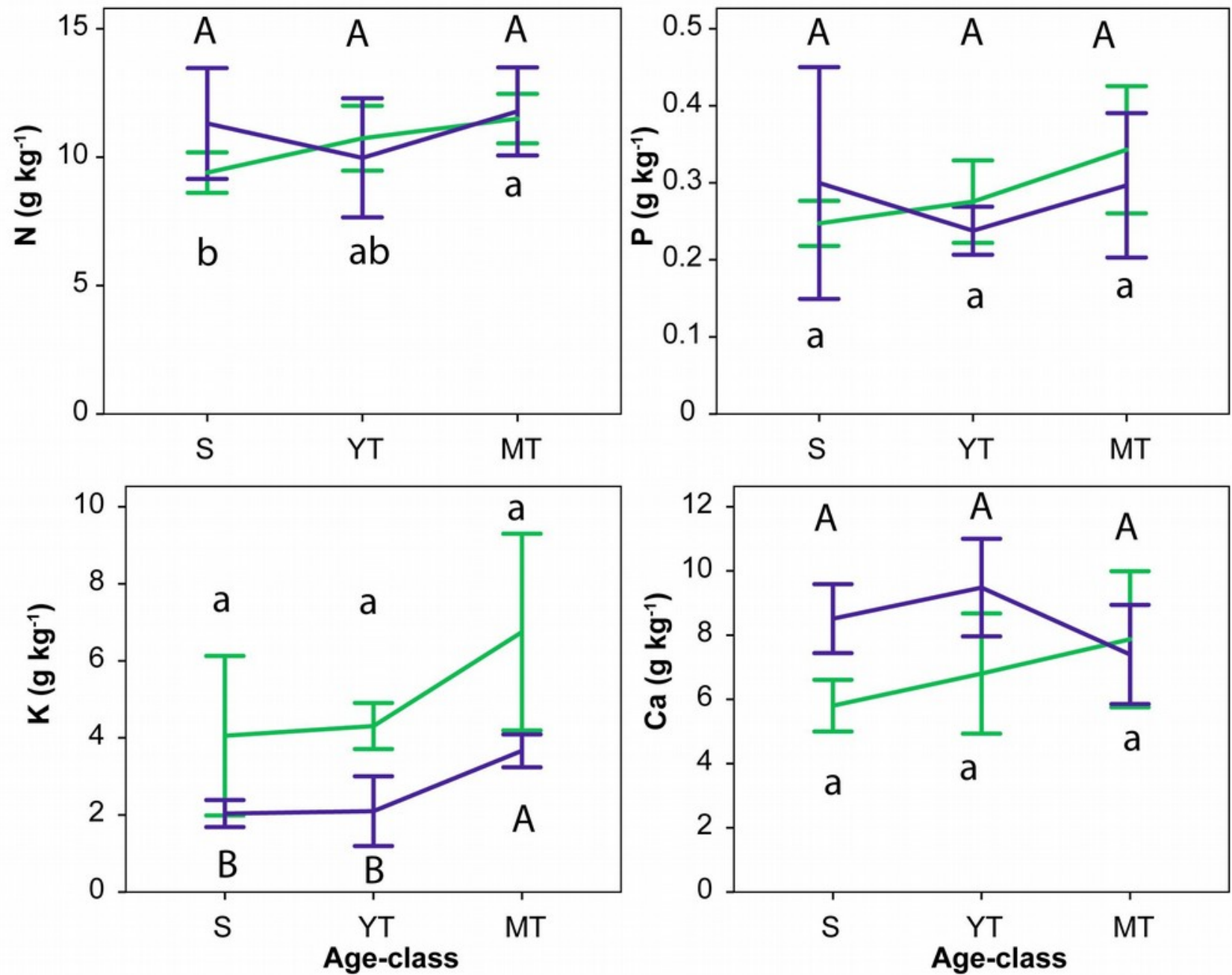
590 Fig. 7:

591
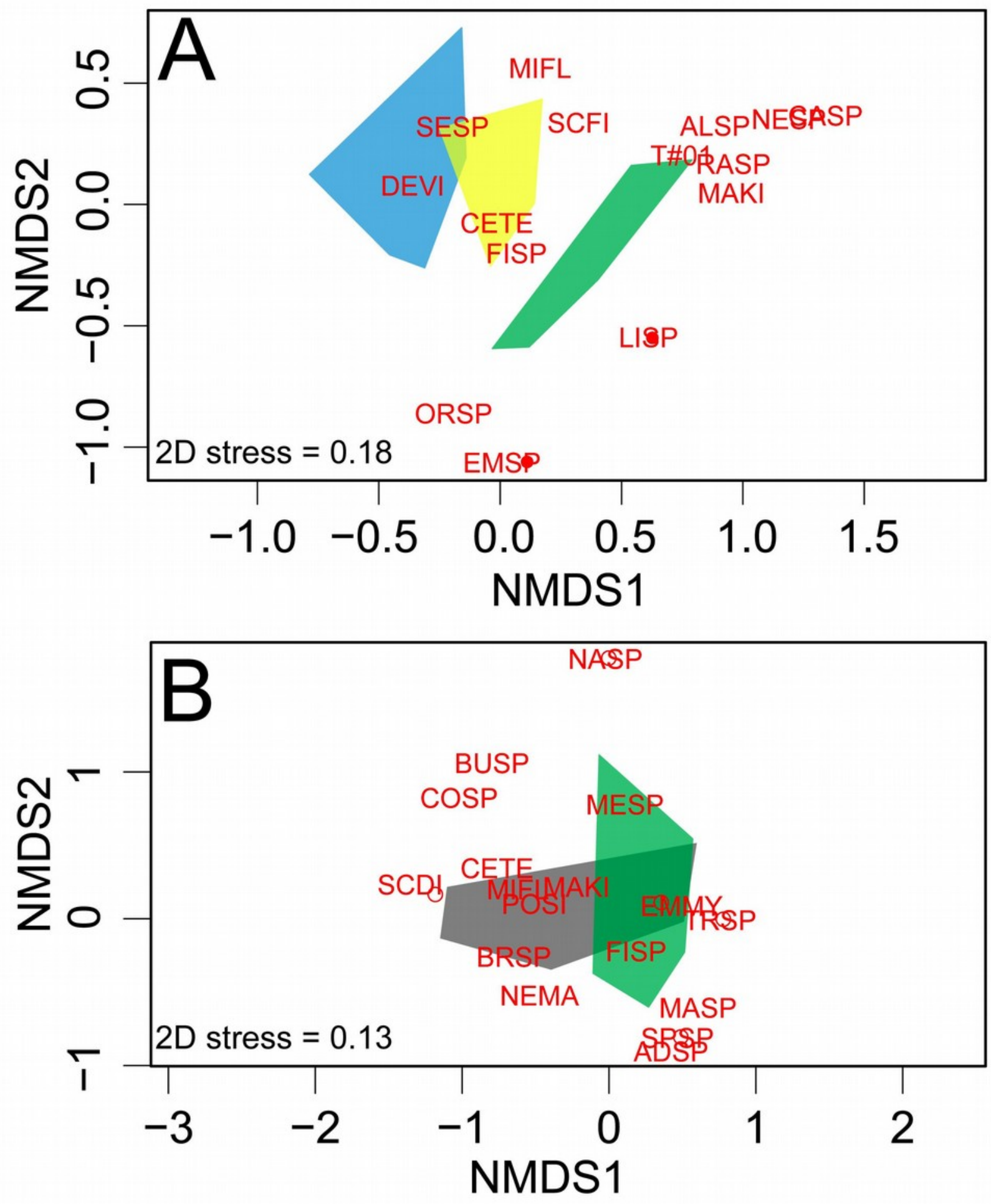

593 